\title{
Parental origin of transcription from the human GNAS1 gene
}

\author{
R Campbell, C M Gosden, D T Bonthron
}

\begin{abstract}
Variation in the phenotypic expression of Albright's hereditary osteodystrophy (AHO) determined by the parent of transmission, suggests that the human Gs $\alpha$ gene (GNAS1), in which mutations occur in AHO, may be under imprinted control. GNAS1 is also known to map to a chromosomal region (20q13.11) showing syntenic homology with the imprinted mouse region 2E1-2H3. To establish if GNAS1 is indeed imprinted, we have examined the parental origin of GNAS1 transcription in human fetal tissues. Of 75 fetuses genotyped, at gestational ages ranging from 6 to 13 weeks, 13 heterozygous for a FokI polymorphism in exon 5 of GNAS1 were identified whose mothers were homozygous for one or other allele. RNA from up to $\mathbf{1 0}$ different tissues from each fetus was analysed by RT-PCR. In all cases expression from both parental alleles was shown by FokI digestion of RT-PCR products and quantification of the resulting fragments. No tissue specific pattern of expression was discerned in these experiments.

If genomic imprinting regulates the expression of the human GNAS1 gene, our data suggest that the effect must either be subtle and quantitative, or be confined to a small subset of specialised hormone responsive cells within the target tissues.
\end{abstract}

( $\mathcal{F}$ Med Genet 1994;31:607-614)

Human Genetics Unit University of Edinburgh, Western General Hospital, Crewe Road, Edinburgh EH4 2XU, UK

R Campbell

D T Bonthron

Department of Obstetrics and Gynaecology, Centre for Reproductive Biology, University of Edinburgh,

37 Chalmers Street, Edinburgh EH3 9EW, UK

R Campbell

MRC Human Genetics Unit, Western General Hospital, Crewe Road, Edinburgh EH4 2XU, UK

C M Gosden

Correspondence to Dr Campbell.

Received 19 January 1994 Accepted for publication 16 March 1994
Albright's hereditary osteodystrophy (AHO) is characterised by obesity, brachydactyly, rounded facies, short stature, and subcutaneous calcification. ${ }^{1}$ Two phenotypic variants exist. In pseudohypoparathyroidism (PHP), hypocalcaemia and hyperphosphataemia, refractory to the administration of exogenous parathormone $(\mathrm{PTH})$, are seen. This results from end organ resistance to the action of PTH. AHO is also seen without these biochemical changes, a situation assigned the term pseudopseudohypoparathyroidism (PPHP). ${ }^{2}$ It is now generally accepted that these two entities are variants of the same disorder, since both may appear in the same family ${ }^{34}$ and a patient's biochemical status may even change with age..$^{56}$

The function of the renal PTH receptoradenylate cyclase signalling pathway is disturbed in these patients. ${ }^{7}$ Reduced expression or altered function of an ubiquitous signalling protein, Gs, has been shown in the erythrocytes of patients with AHO. ${ }^{89} \mathrm{Gs}$, a heterotrimer of $\alpha, \beta$, and $\gamma$ subunits, mediates stimu- lation of adenylate cyclase following binding of PTH to its receptor. Null mutations of the gene encoding the Gs $\alpha$ subunit (GNAS1) have been shown in patients with AHO, ${ }^{1011}$ who may also show defective response to other hormones which act via the adenylate cyclasecAMP system. ${ }^{12-14}$

$\mathrm{AHO}$ is an autosomal dominant disorder, with sex modification accounting for the 2:1 female to male preponderance..$^{15}$ An explanation for the differing phenotypes resulting from GNAS1 mutation, and for the preponderance of maternally inherited PHP cases, has recently been offered. Genomic imprinting of GNAS1 has been suggested, following a review of published cases in which inheritance of the condition from the mother was always seen in PHP, whereas paternal inheritance produced PPHP. ${ }^{16}$ Imprinting of this locus would be consistent with the chromosomal localisation of GNAS1 at 20q13.11, a region showing syntenic homology with the imprinted murine region $2 \mathrm{E} 1-2 \mathrm{H} 3 .{ }^{1718}$

To date, four murine genes have been shown to be imprinted. ${ }^{19-22}$ Three of their human homologues are similarly modified, H19, ${ }^{2324}$ IGF2, ${ }^{2526}$ and SNRPN, ${ }^{27}$ while both IGF2R and IGF1R escape imprinting. ${ }^{2829}$ For each gene, allelic origin has been assigned to mRNA by the use of intragenic polymorphisms; presence or absence of imprinting has usually been considered as an all or none effect. We have now used similar methodology to assign parental origin to GNAS1 cDNA PCR products; allelic expression was quantified in three ways. Our experiments, examining up to 10 different tissue types across a seven week gestational spectrum, have failed to confirm that GNAS1 is under imprinted control in early human embryogenesis. However, it has become apparent that subtle imprinting effects, such as small quantitative differences between paternal and maternal expression, or imprinting confined to a single cell type in one tissue, cannot be ruled out by this type of analysis.

\section{Materials and methods}

TISSUE SAMPLES

With informed maternal consent and ethical committee permission, fetal tissue was collected from surgical terminations of pregnancy at 6 to 12 weeks' gestation, together with a maternal blood sample. Fetal tissues were separated from maternal blood clot and decidua, and individual organs isolated under the dissecting microscope. They were washed in ice cold phosphate buffered saline and immediately homogenised in $4 \mathrm{~mol} / 1$ guanidinium isothiocyanate. Peripheral blood lym- 
phocyte RNA was similarly prepared, after separation of $20 \mathrm{ml}$ venous blood from 20 adult volunteers on Lymphoprep (Nycomed) gradients. These samples were paired with mouthwash samples $(10 \mathrm{ml}$ tap water) from their parents.

\section{NUCLEIC ACID PURIFICATION AND CDNA} SYNTHESIS

Maternal and fetal DNA were extracted from leucocytes and fetal tissues respectively by proteinase $\mathrm{K} / \mathrm{SDS}$ digestion, phenol/chloroform extraction, and ethanol precipitation. The acid guanidinium isothiocyanate/phenol/ chloroform extraction method was used to isolate total RNA from lymphocytes and fetal tissues. ${ }^{30}$

cDNA synthesis was performed using approximately $1 \mu \mathrm{g}$ of total RNA. This was reverse transcribed with $100 \mathrm{U}$ of $M M L V$ reverse transcriptase (Gibco/BRL), priming with $0 \cdot 1 \mu \mathrm{g}$ random hexanucleotides (Pharmacia) in a $30 \mu \mathrm{l}$ reaction volume. Other reaction

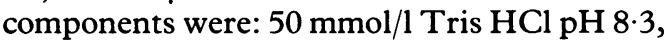
$55 \mathrm{mmol} / 1 \mathrm{KCl}, 3 \mathrm{mmol} / 1 \mathrm{MgCl}_{2}, 100 \mu \mathrm{mol} / 1$ each dNTP, $20 \mathrm{mmol} / \mathrm{l} \mathrm{DTT}$, and $10 \mathrm{U} \mathrm{hu}-$ man placental ribonuclease inhibitor (Gibco/ BRL). Samples were incubated at $37^{\circ} \mathrm{C}$ for 60 minutes and then the reverse transcriptase was denatured at $95^{\circ} \mathrm{C}$ for five minutes; $15 \mu l$ of this cDNA mix was then used for PCR amplification. Negative controls, to which no reverse transcriptase was added, were also amplified.

\section{POLYMERASE CHAIN REACTION}

A single pair of primers was designed to amplify both genomic and cDNA. The sequences were GNAS-4: 5'-AGAAGGCAACCAAAGTGCAGGACA (sense) and GNAS-5: 5'-AGGGAAGTCAAAGTCAGGCACGTT (antisense).

Genomic DNA amplification was performed using $0.5 \mu \mathrm{g}$ DNA template, in the presence of $1 \times \mathrm{PCR}$ buffer $(50 \mathrm{mmol} / 1 \mathrm{KCl}, 10 \mathrm{mmol} / 1$ Tris $\mathrm{HCl} \mathrm{pH} 8.3,1.5 \mathrm{mmol} / 1 \mathrm{MgCl}_{2}, 100 \mu \mathrm{g} /$ $\mathrm{ml}$ gelatin), $0.25 \mu \mathrm{mol} / 1$ each primer, $0.1 \%$ Triton X-100, 1 U Taq polymerase (PerkinElmer Cetus), and $250 \mu \mathrm{mol} / 1$ each dNTP.
PCR cycling was as follows: $94^{\circ} \mathrm{C} / 30$ seconds, $65^{\circ} \mathrm{C} / 30$ seconds, $72^{\circ} \mathrm{C} / 60$ seconds, for 35 cycles, and final extension at $72^{\circ} \mathrm{C} / 10$ minutes. This amplified a fragment of $256 \mathrm{bp}$ (fig 1). cDNA amplification was performed by adding $15 \mu \mathrm{l}$ of the cDNA synthesis product above (including dNTPs) to $35 \mu \mathrm{l}$ of a mix composed of $1 \times$ PCR buffer, primers, Taq polymerase, and gelatin, as above. PCR cycling was as for genomic DNA but for 30 cycles only, and generated a $173 \mathrm{bp}$ product (fig 1). End labelling of primer GNAS-4 was performed with $\gamma^{32} \mathrm{P}$-ATP $(5000 \mathrm{Ci} / \mathrm{mmol}$, Amersham International plc) in the presence of T4-polynucleotide kinase before addition to the cDNA PCR mix.

\section{ANALYSIS OF ALLELIC EXPRESSION}

A Fok I polymorphism in exon $5^{3132}$ was used to genotype DNA and to assign parental origin to each allele in heterozygotes; $3 \mu \mathrm{l}$ of PCR product was digested with $10 \mathrm{U}$ Fok I (New England Biolabs) at $37^{\circ} \mathrm{C}$ for six hours. Predicted cleavage product sizes were $205 / 51 \mathrm{bp}$ for genomic DNA and $122 / 51$ for cDNA. On $3 \%$ agarose gels the small cleavage fragment (51 bp) cannot be resolved from primer-dimer complexes.

${ }^{32} \mathrm{P}$ labelled fragments were separated on $10 \%$ polyacrylamide gels and visualised by ethidium bromide staining. The bands were excised and added to $10 \mathrm{ml}$ Scintran EX $(\mathrm{BDH})$ for direct scintillation counting. Alternatively, the intact gel was fixed in $10 \%$ methanol, $10 \%$ acetic acid, and $5 \%$ glycerol, dried onto Whatman $3 \mathrm{MM}$ paper, and scanned on a Molecular Dynamics model 425E-130 phosphorimager after 20 minute and 40 minute exposures. The band densities were then computer analysed (Imagequant, Molecular Dynamics).

In addition, PCR primer GNAS-4 was fluorescein labelled during synthesis, using Fluorprime (Pharmacia). Fok I digestion products were then analysed on an automated laser fluorescence sequencer (ALF, Pharmacia) and peak areas representing each allele were integrated using the manufacturer's software.

Figure 1 Diagram of part of the GNAS1 gene, showing the positions of the polymorphic FokI site and the PCR primers $G N A S-4 / G N A S-5$. Exons 4 and 5 are indicated by rectangles. Genomic (256 bp) and cDNA (173bp) PCR products are easily distinguished by $3 \%$ agarose gel electrophoresis. 
IMPRINTING OF THE IGF2 GENE

To provide a positive control, the allelic origin of IGF2 expression was also studied, using an ApaI polymorphism (allele frequencies 0.47 / 0.53 ); PCR primers and conditions were as previously reported. ${ }^{263}$ RT-PCR product $(3 \mu \mathrm{l})$ was digested for six hours with $10 \mathrm{U}$ ApaI (Gibco/BRL).

\section{Results}

DISCRIMINATION BETWEEN PARENTAL ALLELES OF GNAS

Genomic DNA from 75 fetuses was typed for a $\mathrm{C} / \mathrm{T}$ polymorphism in exon 5 of GNAS 1 by Fok I digestion of the $256 \mathrm{bp}$ PCR product (fig 1). Thirty-nine fetuses were heterozygous. To assign a parental identity to each allele, maternal genomic DNA, obtained from peripheral blood, was typed. Since paternal DNA was not available, the only informative situation for these experiments was one in which the mother was homozygous at the Fok I site. Thirteen such mother-fetus pairs were identified and analysed further.

\section{BIALLELIC EXPRESSION OF GNAS}

Total RNA was isolated from available fetal organs and reverse transcribed before PCR amplification. Up to 10 tissue types were analysed from each fetus (table 1), the material spanning 6 to 13 weeks of gestation. The RTPCR product ( $173 \mathrm{bp}$ ) was easily distinguishable from the $256 \mathrm{bp}$ genomic DNA product (figs 1 and 2A), providing a control for any genomic DNA contamination of the RNA. Such contamination was in fact never seen. After Fok I digestion, visual assessment of ethidium stained 3\% agarose gels indicated roughly equivalent biallelic expression in all fetal tissues at all gestational ages (fig 2A). IGF2 expression by comparison, in the same tissues from fetuses DM09 and LR19, showed exclusive paternal transcription, consistent with previous reports ${ }^{2526}$ (fig $2 \mathrm{~B}$ ).
QUANTIFICATION OF ALLELIC EXPRESSION

Three methods were used to quantify the relative expression of each parental allele. Firstly, cDNA-PCR was performed in the presence of ${ }^{32} \mathrm{P}$ end labelled oligonucleotide primer GNAS4 (fig 1). The relative expression of each allele was then quantified by excision of the bands from an acrylamide gel and scintillation counting, or by phosphorimager analysis of the fixed dried gel (fig 3).

Finally, an alternative non-radioactive technique, using a fluorescein labelled primer (again GNAS-4) and automated laser fluorescence (ALF), was used. The amounts of digested and undigested cDNA-PCR product were estimated by computer integration of the peak areas corresponding to each fragment (fig 4).

As shown in detail in tables 2 to 4 , all three analytical methods suggested a slight predominance (ratio $\sim 1 \cdot 2$ ) of expression from the maternal GNAS1 allele. However, this effect did not reach statistical significance for the data generated from fluorescein labelling and automated peak integration (table 4). It is further discussed below.

\section{GNAS1 EXPRESSION BY PERIPHERAL BLOOD LYMPHOCYTES}

Following the above experiments, a second source of RNA was studied. In this experiment, DNA and RNA were extracted from peripheral blood from persons in one generation, and mouthwash DNA was later obtained from the parental generation. This was designed to eliminate any bias introduced by possible maternal blood/tissue contamination of our fetal samples. Twenty persons were genotyped and in those heterozygous for the Fok I polymorphism $(n=13)$, the relative expression of each parental allele in lymphocyte RNA was measured as above. Only then were the parents of these 13 persons genotyped. This showed seven informative persons in whom one or both parents were homozygous,

Table 1 Range of tissues examined in 13 informative fetuses. Gestational ages are indicated in weeks. The fetuses are separated into two groups to allow for the detection of possible systematic errors owing to incomplete restriction enzyme digestion; their mothers are homozygous either for presence $(n=7)$ or absence $(n=6)$ of the FokI restriction site
allow for the detection of possible systematic errors owing

\begin{tabular}{|c|c|c|c|c|c|c|c|c|c|c|c|c|}
\hline \multirow[t]{2}{*}{ Fetus no } & \multirow{2}{*}{$\begin{array}{c}\text { Gestation } \\
\text { (weeks) }\end{array}$} & \multicolumn{11}{|l|}{ Tissues } \\
\hline & & Heart & $S p$ cord & Muscle & Kidney & Lung & Gut & Eye & Brain & Adrenal & Stomach & Gonad \\
\hline \multicolumn{13}{|c|}{$\begin{array}{l}\text { Maternal allele upper } \\
\text { (uncut) }(n=6)\end{array}$} \\
\hline $\begin{array}{l}\text { MC2601 } \\
\text { CA2505 }\end{array}$ & $\begin{array}{r}10 \\
6\end{array}$ & + & & + & & + & + & + & + & & & \\
\hline $\begin{array}{l}\text { CA2505 } \\
\text { LF0101 }\end{array}$ & $\begin{array}{r}6 \\
10\end{array}$ & + & + & $\begin{array}{l}+ \\
+\end{array}$ & + & & + & & $\begin{array}{l}+ \\
+\end{array}$ & & & \\
\hline FB1103 & 12 & + & & + & + & + & + & + & + & + & & \\
\hline SN3010 & 8 & + & + & + & & & & & & & & \\
\hline LR1907 & 13 & + & + & + & + & & + & + & + & + & + & + \\
\hline \multicolumn{13}{|c|}{$\begin{array}{l}\text { Maternal allele lower (cut) } \\
(n=7)\end{array}$} \\
\hline NG1003 & 6 & & & & & & & & + & & & \\
\hline DB2807 & 8 & & + & + & & & & & + & & & \\
\hline HW 3004 & 11 & + & + & + & & & & + & & & & \\
\hline EH1311 & 8 & & + & + & & + & & & & & & \\
\hline DM0909 & 9 & & & + & & + & + & & + & & & \\
\hline MT1509 & 7 & & + & + & & & $\cdot$ & & & & & \\
\hline HM1709 & 10 & + & + & + & & + & + & & & & & \\
\hline
\end{tabular}




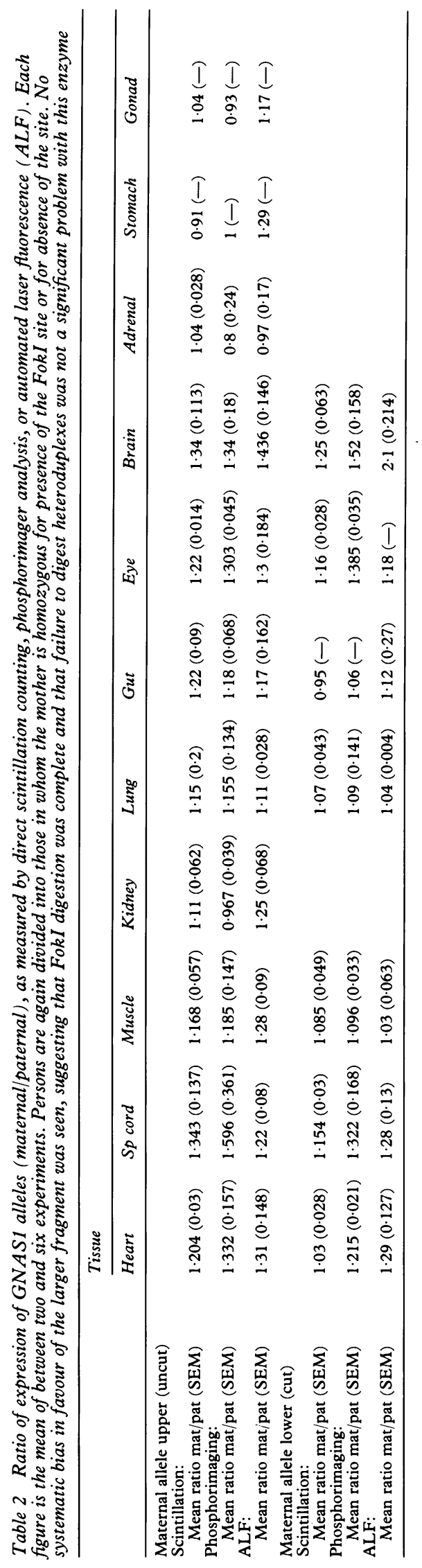



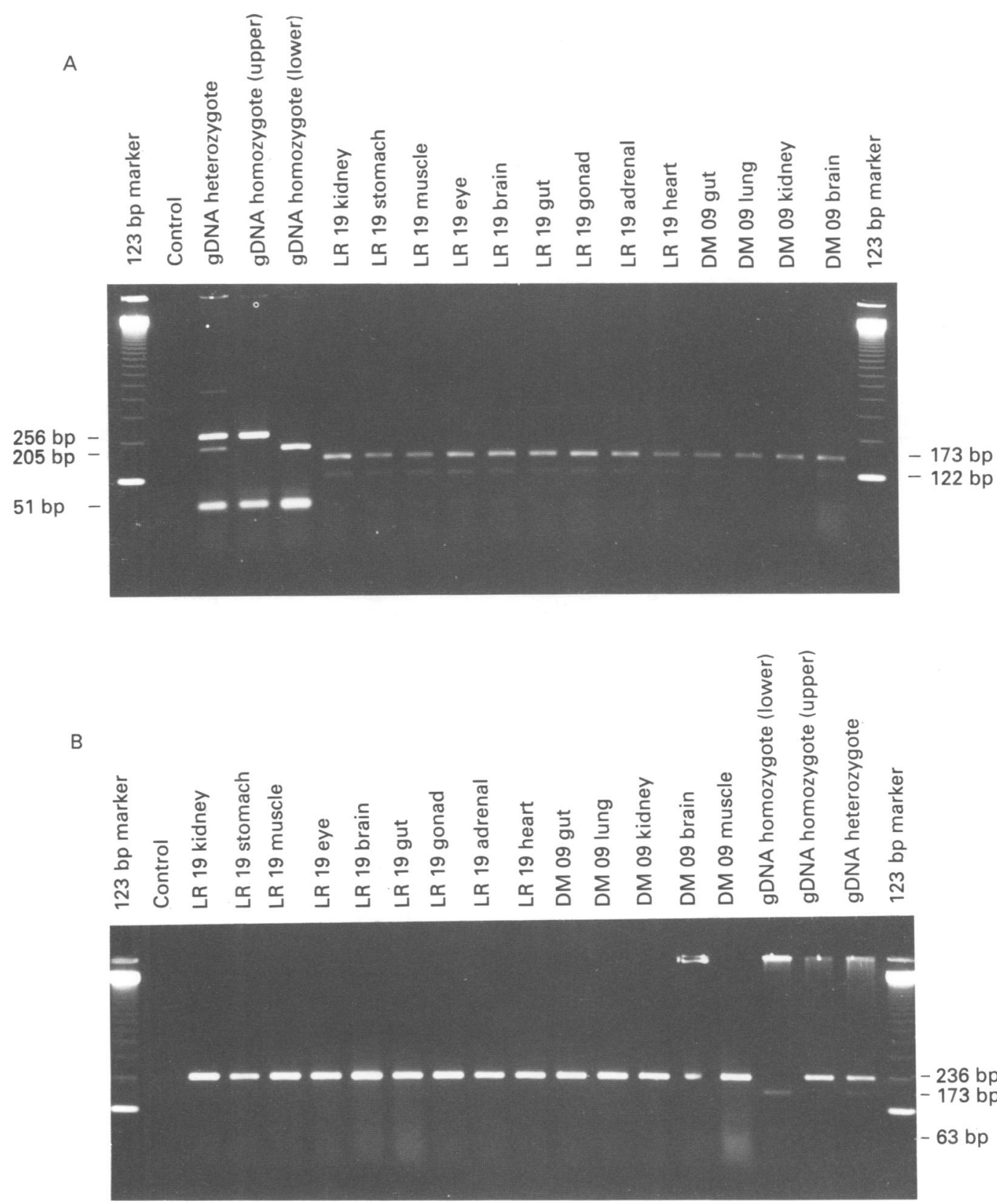

Figure 2 (A) Biallelic expression of GNAS1, shown by FokI digestion of RT-PCR products derived from 10 different tissue types. Both $173 \mathrm{bp}$ (undigested) and $122 \mathrm{bp}$ (digested) fragments are present. Both of these fetuses werc heterozygous for the FokI polymorphism, the maternal allele being the upper (LR 19) or lower (DM 09) band respectively. An apparent increase in density of the upper band is artefactual owing to counter migration of ethidium bromide. Genomic DNA PCR controls, showing homozygosity for both lower (205 bp) and upper (256 bp) bands, and heterozygosity are shown for comparison. The marker is a $123 \mathrm{bp}$ DNA ladder. FokI possesses an asymmetrical recognition site (GGATG) and cleaves the ds-DNA 9 base pairs downstream." This suggests the possibility that this enzyme may be capable of cleaving one or other of the heteroduplexes generated by PCR in heterozygotes. In support of this, a consistent bias in favour of the upper (uncut) fragment was not encountered suggesting complete digestion. (B) Monoallelic expression of IGF2, shown by ApaI digestion of RT-PCR products. Fetuses LR 19 and DM 09 were again informative, the paternal allele in both cases being represented by an undigested product. They were used to show exclusive paternal expression ( $236 \mathrm{bp}$ ), with absence of a maternal $R T-P C R$ product ( $173 \mathrm{bp}$ ) in all 10 tissue types examined. Genomic DNA controls as in fig $2 A$ are shown for comparison. Digestion of genomic DNA PCR products from heterozygotes consistently showed greater intensity of the uncut product suggesting failure of ApaI (with a symmetrical recognition site, GGGCCC) to digest heteroduplexes. ${ }^{35} 42$ This experiment indicates evidence of imprinting in a wider selection of human fetal tissues and at earlier gestational ages than has previously been reported.

Table 3 Ratio of expression of GNAS1 alleles (maternal/paternal) in adult lymphocytes. Seven informative persons are represented. Scintillation counting (single experiment), phosphorimager analysis, and $A L F$ (mean of six experiments) showed no significant predominance of maternal to paternal expression

\begin{tabular}{|c|c|c|c|c|c|c|c|}
\hline & $M B 2906$ & F70603 & $L C 1303$ & EG3011 & CM3110 & KM0903 & LF0105 \\
\hline $\begin{array}{l}\text { Scintillation: } \\
\text { Ratio mat/pat }\end{array}$ & 0.87 & $1 \cdot 16$ & $1 \cdot 26$ & $1 \cdot 41$ & $0 \cdot 85$ & $1 \cdot 1$ & $1 \cdot 88$ \\
\hline $\begin{array}{l}\text { Phosphorimaging: } \\
\text { Mean ratio mat/pat (SEM) }\end{array}$ & $1.23(0.073)$ & $0.95(0.066)$ & $1.04(0.089)$ & $1 \cdot 24(0 \cdot 19)$ & $1.08(0.061)$ & $1 \cdot 0(0 \cdot 102)$ & $1 \cdot 1(0 \cdot 13)$ \\
\hline Mean ratio mat/pat (SEM) & $0.99(0.062)$ & $0.87(0.075)$ & $1.35(0 \cdot 106)$ & $1.4(0.122)$ & $1.5(0.101)$ & $1.07(0.095)$ & $1.15(0.069)$ \\
\hline
\end{tabular}




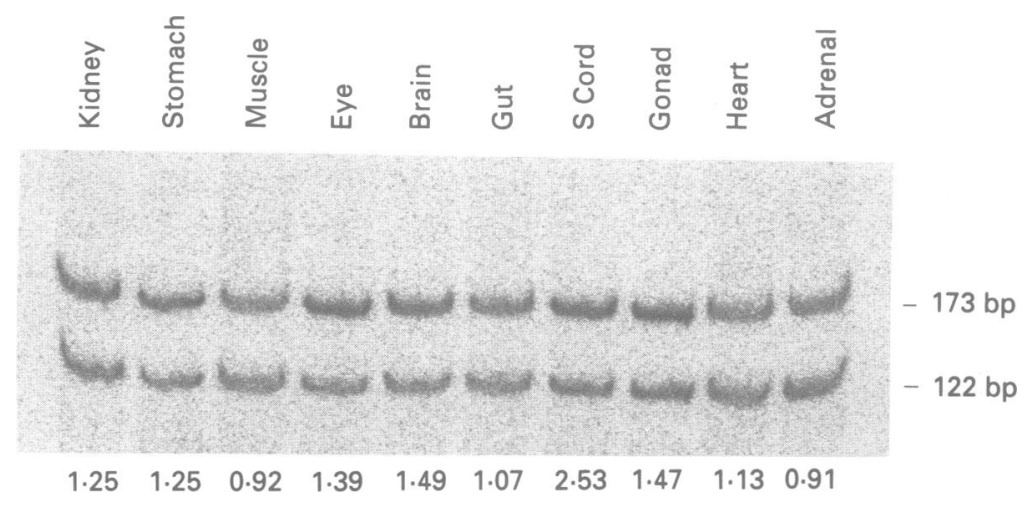

Figure 3 Phosphorimager analysis of a $10 \%$ polyacrylamide gel, showing biallelic expression of GNAS1 following FokI digestion of $R T-P C R$ products from fetus $L R$ 19. Ten tissue types are shown. Below each lane are the values obtained by quantification of each band, expressed as a ratio of maternal (upper): paternal (lower) allele.
For some imprinted genes, privileged tissues may fail to silence the imprinted allele. ${ }^{21} 28$ This implies that control of imprinting can operate in a tissue specific manner. Furthermore, in individual tissues, some imprinted genes may also show incomplete transcriptional repression. ${ }^{36-38}$ The mechanism underlying the latter observation could be either biallelic expression by certain cell types within a tissue, or alternatively partial silencing of one allele in all cells of such tissues. Both of these observations suggest that imprinting is not necessarily an "all or nothing" phenomenon. An analogy which may be drawn is that of partial escape from $\mathrm{X}$ inactivation by certain genes, including the human steroid sulphatase gene. ${ }^{39} \mathrm{~A}$ measure of the ratio of female to male steroid sulphatase activity (XX dosage: $\mathrm{XY}$ dosage) yields a range of $1 \cdot 42,1 \cdot 7$, or $1 \cdot 8: 1^{34} 3540$ rather than the $1: 1$ or $2: 1$ values expected for complete inactivation or non-inactivation of this gene respectively.

If GNAS1 is under imprinted control, such control is unlikely to operate in a simple global way. In erythrocytes of patients with PHP type 1a, Gs activity is reduced to about half normal, rather than being 0 or $100 \%$ as expected for a completely imprinted gene. This suggests the possibility of cell type specific or subtle quantitative imprinting effects. It was for this reason that we surveyed a wide range of different tissues and quantitated relative levels of expression as far as was possible.

Both of our ${ }^{32} \mathrm{P}$ based assays suggested a small preponderance of maternal over paternal expression (ratio $\sim 1 \cdot 2$ ) in virtually all tissues examined (tables 2 and 3 ). A similar but nonsignificant trend was seen using the fluorescein labelling protocol; this assay disappointingly and at all gestations.

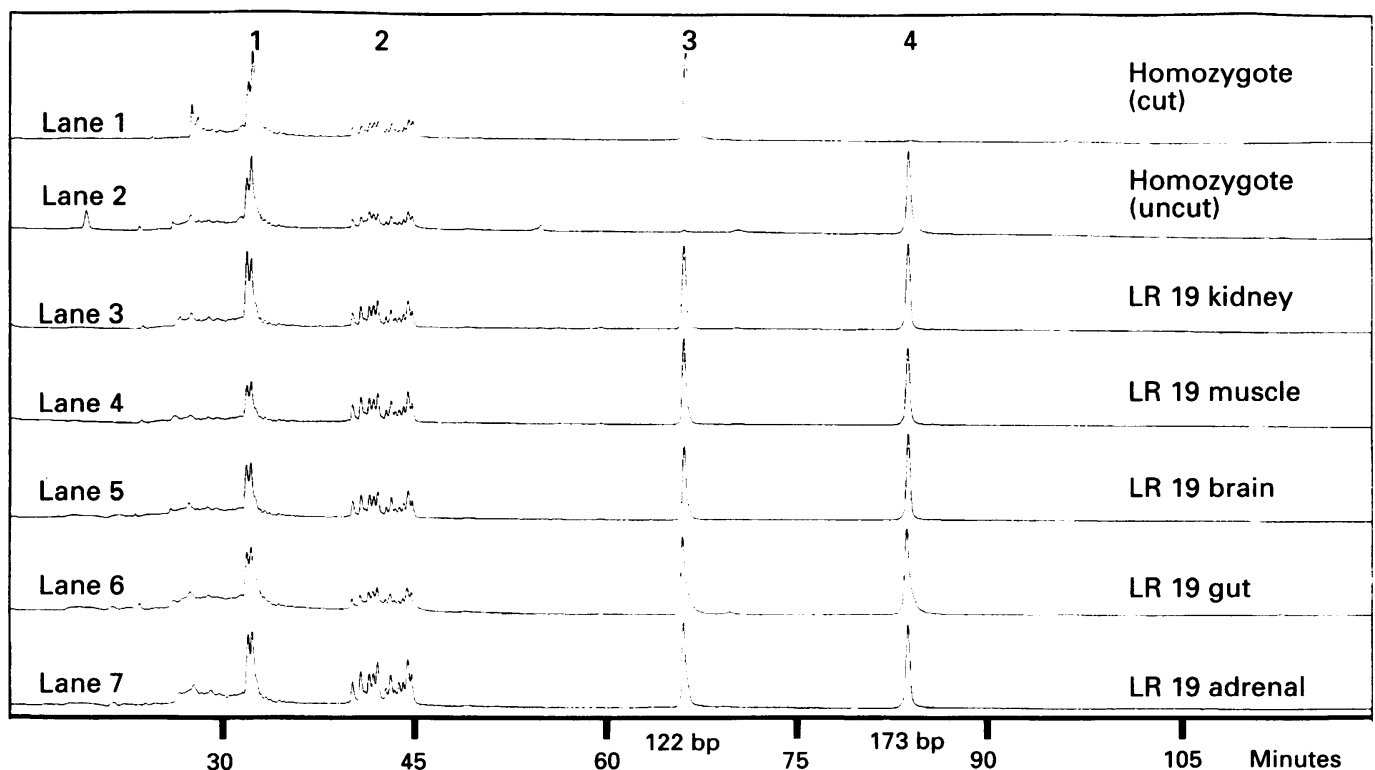

Figure 4 Analysis of allelic expression of GNAS1 by automated laser fluorescence.

Peaks 1-4 represent the fluorescent primer peak, primer-dimer complexes, and digested

(122 bp) and undigested (173 bp) GNAS1 products respectively. Lanes 1 and 2 show

results obtained from fetuses homozygous for cut and uncut fragments. Lanes 3-7

represent the heterozygous fetus LR 19 (kidney, muscle, brain, gut, adrenal) and show the equivalence of maternal and paternal peak sizes. 
displayed a rather greater degree of random variability. Although a slight maternal predominance of transcription would provide a possible explanation for the more severe phenotype observed on maternal transmission of PHP/PPHP, we do not consider that our results prove this point. There is a risk that contamination of the fragmented fetal tissues by maternal blood or tissue could give rise to a similar effect, despite the careful washing which was performed. To address this possibility, the analysis of adult peripheral blood lymphocyte GNAS1 expression was undertaken. Not only was this experiment free from possible maternal contamination effects, but it was also performed blinded, the RT-PCR quantification being performed before the parental genotypes were revealed. Table 3 shows that a reproducible difference in expression levels between the maternal and paternal alleles was not obtained in this experiment.

If GNAS1 imprinting is a tissue specific phenomenon, it should be possible from the phenotypic features of AHO to predict which tissues might be involved. These would include PTH target tissues and other endocrine organs in which adenylate cyclase was the second messenger and whose function is disrupted in AHO, namely kidney (proximal tubule), thyroid, gonad, and bone. Why such embryologically diverse tissues should share a common transcriptional control mechanism is, however, difficult to explain. We have been unable to show a target tissue specific effect at the whole organ level, having examined kidneys from three fetuses and one pair of fetal ovaries. It remains possible, though, that imprinting is limited to a specific subset of hormone sensitive cells. If so, examining the whole fetal kidney might not show such an effect, as the PTH sensitive proximal renal tubular epithelial cells would form a tiny proportion of the total tissue.

In summary, we have found no compelling experimental evidence that GNAS1 is under imprinted control, despite the strong clinical evidence supporting such an effect. Prospective study of further AHO pedigrees, combined with mutational analysis, may shed further light on the underlying postulate of imprinted inheritance of PHP and PPHP.

We thank Alison Rae for operation of the ALF machine, and acknowledge the help with specimen collection of our clinical colleagues at the Royal Infirmary of Edinburgh. Ethical Com mittee permission and supervision of the fetal work was by the Lothian Health Board Medicine/Oncology and Reproductive Medicine/Paediatric Ethical Committees. We thank Professo D J H Brock in whose unit the experimental work was performed. This work was jointly supported by the University Edinburgh (Cancer Research Fund) and the Medical Research Council. RC is an MRC research training fellow.

1 Albright F, Burnett $\mathrm{CH}$, Smith PH, Parson W. Pseudohypoparathyroidism - an example of "Seabright-Bantam" syndrome. Endocrinology 1942;30:922-32.

2 Albright F, Forbes AP, Henneman PH. Pseudo-pseudohypoparathyroidism. Trans Assoc Am Physicians 1952; 65:337-50.

3 Arnstein AR, Frame B, Frost HM, Block MA. Albright's hereditary osteodystrophy. Ann Intern Med 1966;64:9961008.

4 Boscherini B, Coen G, Bianchini G, et al. Albright's hereditary osteodystrophy. Acta Paediatr Scand 1980;69:305-9.

5 Farriaux AJP. Pseudohypoparathyroidism. Biting insect summary. Am J Dis Child 1976;130:780-1.
6 Moses AM, Breslau N, Coulson R. Renal responses to PTH in patients with hormone resistant (pseudo)hypoparathyroidism. Am f Med 1976;61:184-9.

7 Chase LR, Melson GL, Aurbach GD. Pseudohypoparathyroidism: defective secretion of $3^{\prime}, 5^{\prime}$-AMP in response to parathyroid hormone. $\mathcal{f}$ Clin Invest 1969;48:1832-44.

8 Levine MA, Downs RW Jr, Singer M, Marx SJ, Aurbach GD, Spiegel AM. Deficient activity of guanine nucleotide regulatory protein in erythrocytes of patients with pseudohypoparathyroidism. Biochem Biophys Res Commun 1980;94:1319-24.

9 Levine MA, Jap T, Mauseth RS, Downs RW, Spiegel AM. Activity of the stimulatory guanine nucleotide-binding protein is reduced in erythrocytes from patients with preudohypoparathyroidism and pseudopseudohypoparapseudohypoparathyroidism and pseudopseudohypopara-
thyroidism: biochemical, endocrine and genetic analysis of thyroidism: biochemical, endocrine and genetic analysis of
Albright's hereditary osteodystrophy in six kindreds. $\mathcal{f}$ Albright's hereditary osteodystrophy in
Clin Endocrinol Metab 1986;62:497-502.

10 Patten JL, Johns DR, Valle D, et al. Mutation in the gene encoding the stimulatory $\mathrm{G}$ protein of adenylate cyclase in Albright's hereditary osteodystrophy. $N$ Engl $\mathcal{F} \mathrm{Med}$ 1990;322:1412-19.

11 Weinstein LS, Gejman PV, Freidman E, et al. Mutations of the Gs alpha-subunit gene in Albright's hereditary osteodystrophy detected by denaturing gel electrophoresis. Proc Natl Acad Sci USA 1990;87:8287-90.

12 Zisman E, Lotz M, Jenkins ME, Bartter FC. Studies in pseudohypoparathyroidism. Two new cases with a probable selective deficiency of thyrotropin. $A m f \mathrm{Med}$ 1969;46:464-71.

13 Wolfsdorf JI, Rosenfeild RL, Fang VS, Kobayashi R, Razdan AK, Kim MH. Partial gonadotropin-resistance in pseudohypoparathyroidism. Acta Endocrinol 1978;88:3218 .

14 Levine MA, Downs RW, Moses AM, et al. Resistance to multiple hormones in patients with pseudohypoparathyroidism. Am f Med 1983;74:545-56.

15 Fitch N. Albright's hereditary osteodystrophy: a review. $\mathrm{Am}$ 7 Med Genet 1982;11:11-29.

16 Davies SJ, Hughes HE. Imprinting in Albright's hereditary osteodystrophy. F Med Genet 1993;30:101-3.

17 Cattanach BM, Kirk M. Differential activity of maternally and paternally derived chromosome regions in mice. Nature 1985;315:496-8.

18 Cattanach BM, Beechey CV. Autosomal and X-chromosome imprinting. Development Suppl 1990;63-72.

19 Barlow D, Stroger R, Herrman B, Saito K, Schweifer N. The mouse insulin-like growth factor type-2 receptor is imprinted and closely linked to the Tme locus. Nature 1991;349:84-7.

20 Bartolomei M, Zemel S, Tilghman S. Parental imprinting of the mouse H19 gene. Nature 1991;351:153-5.

21 DeChiara T, Robertson E, Efstratiadis A. Parental imprinting of the mouse insulin-like growth factor 2 gene. Cell

22 Leff SE, Brannan CI, Reed ML, et al. Maternal imprinting of the mouse Snrpn gene and conserved linkage homology with the human Prader-Willi syndrome region. Nature Genet 1992;2:259-64.

23 Zhang Y, Tycko B. Monoallelic expression of the human H19 gene. Nature Genet 1992;1:40-3

24 Zhang Y, Shields T, Crenshaw T, Hao Y, Moulton T, Tycko B. Imprinting of human H19. Allele-specific CpG methylation, loss of the active allele in Wilms tumour, and potential for somatic allele switching. Am $f$ Hum Genet 1993;53:113-24.

25 Ohlsson R, Nystrom A, Pfeifer-Ohlsson S, et al. IGF2 is parentally imprinted during human embryogenesis and in the Beckwith-Wiedemann syndrome. Nature Genet 1993;4:94-7.

26 Giannoukakis N, Deal C, Paquette J, Goodyer CG, Polychronakos C. Parental genomic imprinting of the human IGF2 gene. Nature Genet 1993;4:98-101.

27 Glenn CC, Porter KA, Jong MTC, Nicholls KD, Driscoll DJ. Functional imprinting and epigenetic modification of

28 Kalscheuer VM, Mariman EC, Schepens MT, Rehder H, Ropers $\mathrm{HH}$. The insulin-like growth factor type-2 receptor gene is imprinted in the mouse but not in humans. Nature Genet 1993;5:74-8.

29 Ogawa O, McNoe LA, Eccles MR, Morison IM, Reeve AE. Human insulin-like growth factor type I and type II receptors are not imprinted. Hum Mol Genet 1993; 12:2163-5.

30 Chomczynski P, Sacchi N. Single step method of RNA isolation by acid guanidinium thiocyanate-phenol-chloroform extraction. Anal Biochem 1987;162:156-9.

31 Kozasa $\mathrm{T}$, Itoh $\mathrm{H}$, Tsukamoto $\mathrm{T}$, Kaziro $\mathrm{Y}$. Isolation and characterisation of the human Gs $\alpha$ gene. Proc Natl Acad Sci USA 1988;85:2081-5.

32 Geiman PV, Weinstein LS, Martinez M, et al. Genetic mapping of the Gs- $\alpha$ subunit gene (GNAS1) to the distal long arm of chromosome 20 using a polymorphism detected by denaturing gradient gel electrophoresis. Genomics 1991;9:782-3.

33 Tadokoro K, Fujii H, Inoue T, Yamada M. Polymerase chain reaction (PCR) for detection of ApaI polymorphism at the insulin-like growth factor II gene (IGF2). Nucleic Acids Res 1991;19:6967.

34 Sasaki H, Jones PA, Chaillet JR, et al. Parental imprinting: potentially active chromatin of the repressed materna allele of the mouse insulin-like growth factor II (IGF2) gene. Genes Devel 1992;6:1843-56.

35 Weksberg R, Shen DR, Fei YL, Song QL, Squire J. Disruption of insulin-like growth factor 2 imprinting in Beckwith 
Wiedemann syndrome. Nature Genet 1993;5:143-50.

36 Mutter GL, Stewart CL, Chaponot ML, Pomponio RJ Oppositely imprinted genes $\mathrm{H} 19$ and insulin-like growth factor II are co-expressed in human androgenetic trophoblast. Am f Hum Genet 1993;53:1096-102

37 Mohandas TK, Stern HJ, Meeker CA, et al. Steroid sulfatase gene in XX males. Am F Hum Genet 1990;46:369-76.

38 Muller CR, Migl B, Traupe H, Ropers HH. X-linked steroid sulfatase: evidence for different gene-dosage in males and females. Hum Genet 1980;54:197-9.

39 Lykkesfeldt G, Bock JE, Lykkesfeldt AE. Sex specific dif- ference in placental steroid sulphatase activity. Lancet 1981;ii:255-6.

40 Lykkesfeldt G, Lykkesfeldt AE, Skakkebaek NE. Steroid sulphatase in man: a non inactivated $X$-locus with partia gene dosage compensation. Hum Genet 1984;65:355-7.

41 Sugisaki H, Kanazawa $S$. New restriction endonuclease from Flavobacterium okeanokoites (FokI) and Micrococcus luteus (MluI). Gene 1981;16:73-8.

42 Ogawa O, Eccles MR, Szeto J, et al. Relaxation of insulinlike growth factor II gene imprinting implicated in Wilms tumour. Nature 1993;362:749-51. 